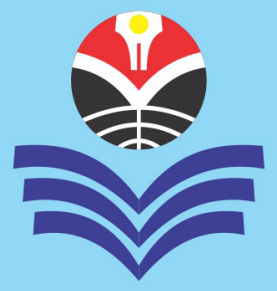

\title{
Approximate Behaviors as Cues for Addressing Learning Needs
}

\begin{abstract}
The behavior of learners can serve as cue, so that teachers would make the necessary adjustments in handling the class. However, when this behavior becomes intolerable, some people call it misbehavior. In this light, behavior which is usually recognized as distressing can be viewed with optimism. Too much hand and body movement of children inside or outside classroom can be viewed as indicating a favorable need for action, a call for alternative process to achieve learning. This study attempted to present an alternative view of first grade learners' behavior during reading sessions in class. For gathering of data, a checklist was used to observe one participant-learner every scheduled reading class. The first grade learners' reading difficulties can be manifested through various behaviors. These behaviors are grouped and can be observed on four areas, such as head, arm-hand, shoulder-waist, and waist-foot. The approximate behaviors as cues for addressing learning needs have similar postures found in brain gym movements. It is recommended that other areas of learning difficulty among school learners be explored. Further, identify the learning difficulties in reading and the behaviors of school learners using the checklist constructed by the researchers.
\end{abstract}

KEY WORD: Behavior; Cues for Learning Needs; Learning Difficulty; Brain Gym Movements.

ABSTRAKSI: "Perkiraan Perilaku sebagai Isyarat untuk Mengatasi Kebutuhan Belajar". Perilaku peserta didik dapat dijadikan isyarat, sehingga guru dapat melakukan penyesuaian yang diperlukan dalam penanganan kelas. Namun, bila perilaku ini menjadi tidak tertahankan, beberapa orang menyebutnya perilaku salah. Dalam hal ini, perilaku yang biasanya dikenali sebagai hal yang menyedihkan dapat dilihat dengan optimisme. Terlalu banyak gerakan tangan dan tubuh anak-anak di dalam atau di luar kelas dapat dipandang sebagai indikasi kebutuhan tindakan yang baik, sebuah panggilan dalam proses alternatif untuk mencapai pembelajaran. Penelitian ini mencoba menyajikan pandangan alternatif tentang perilaku peserta didik di kelas satu selama sesi membaca di kelas. Untuk pengumpulan data, daftar isian ceklis digunakan dalam mengamati satu peserta didik di setiap kelas pembacaan yang dijadwalkan. Kesulitan membaca peserta didik kelas satu dapat diwujudkan melalui berbagai perilaku. Perilaku ini dikelompokkan dan dapat diamati pada empat bidang, seperti kepala, lengan-tangan, bahu-pinggang, dan pinggang-kaki. Perkiraan perilaku sebagai isyarat untuk mengatasi kebutuhan belajar memiliki postur tubuh serupa yang ditemukan pada gerakan asah otak. Disarankan agar daerah lain yang mengalami kesulitan belajar di antara siswa sekolah dapat dieksplorasi. Selanjutnya, identifikasi kesulitan belajar membaca dan perilaku pelajar sekolah menggunakan daftar isian ceklis yang disusun oleh para peneliti.

KATA KUNCI: Perilaku; Isyarat untuk Kebutuhan Belajar; Kesulitan Belajar; Gerakan Asah Otak.

About the Authors: Jose M. Ocampo, Jr., Ph.D. is a Full Professor at the Faculty of Education Sciences PNU (Philippine Normal University) in Manila, Philippines. Laura V. Ocampo, M.A. is a Science Grade School Teacher at the Claret School of Quezon City, Philippines. For academic interests, the authors are able to be contacted via e-mails at: juno_6970@yahoo.com and hope4619@gmail.com

Suggested Citation: Ocampo, Jr., Jose M. \& Laura V. Ocampo. (2018). “Approximate Behaviors as Cues for Addressing Learning Needs" in MIMBAR PENDIDIKAN: Jurnal Indonesia untuk Kajian Pendidikan, Volume 3(1), March, pp.1-10. Bandung, Indonesia: UPI [Indonesia University of Education] Press, ISSN 2527-3868 (print) and 2503-457X (online).

Article Timeline: Accepted (February 8, 2018); Revised (March 11, 2018); and Published (March 30, 2018). 


\section{INTRODUCTION}

The behavior of learners, even before performance evaluation is conducted, can serve as cue so that teachers would make the necessary adjustments in handling the class. However, when this behavior becomes intolerable, some people call it misbehavior. If behavior is taken in cognizance as a hostile mechanism to get someone's attention, an act of vengeance, or to strive for superiority, it is probable that the said behavior could mean something else (Sibley \& Etnier, 2003; Formosa, 2009; and Ocampo, Jr., 2015a and 2015b).

In this light, behavior which is usually recognized as distressing can be viewed with optimism. Too much hand and body movement of children inside or outside classroom can be viewed as indicating a favorable need for action, a call for alternative process to achieve learning. Sometimes, C. Hannaford (1997) clarifies that children who are under stress may be able to express themselves with hand and body gestures. As extreme bodily behaviors can be a manifestation of learning difficulty, an experience when children fail to adjust in order to learn, it is hereby proposed that one ponder on the idea that behavior can be considered a learning cue. Hence, teachers have to put premium on considering these cues for the facilitation of learning among pupils (Hannaford, 1997).

By observing a child who is struggling to learn, one may sense that he has learning difficulty. It can be deduced, sometimes, that he is exhibiting intolerable behaviors. However, even for those whose movement is limited, new learning can occur along motor pathways activated by subtle or imagined movement (Koester \& Dennison, 1994 and 2010). In addition, activities in the natural environment may be even more vital for children (Sarivaara, 2018). The initial process to address learning difficulty is through its identification. Hence, beyond the orientation of ratings and grades, behavior serves as a starting point for noticing learning difficulty (Tambychick, 2010; Dunlosky et al., 2013; and ADB, 2015).

It is necessary that intervention techniques have to be searched, one of which is Brain Gym composed of exercises using bodily movements (Dennison \& Dennison, 1994 and 2010; Mahar et al., 2006; and Watson \& Kelso, 2014). It includes a set of 26 exercises claimed to bring about rapid and often dramatic improvements in concentration, memory, reading, writing, organizing, listening, penmanship, and more. Further, they suggest these activities when learners manifest behaviors, such as bending forward, slouching while sitting, staring, swinging the arms, and the like (Feldman et al., 2003; and Otto \& Hofmann eds., 2010).

Different studies were conducted to validate whether or not these exercises have been found effective in reducing children's learning difficulties. A study by B. Maskell, D.R. Shapiro \& C. Ridley (2004) on the effects of brain gym first grade students were tested before and after a 5-week intervention using the object control subtest from the Jest of Gross Motor Development-2. The throwing criteria included: (1) windup initiated with downward movement of hand/arm; (2) rotates hip and shoulders so non-throwing side faces the wall; (3) weight transferred by stepping with foot opposite throwing hand; and (4) follow-through diagonally across body toward non-preferred side (Ulrich \& Sanford, 2000; and Maskell, Shapiro \& Ridley, 2004).

D. Reynolds, R. Nicolson \& H. Hambly (2003) wrote an article promotes the helpful academic advantage of a perceptual - motor training, especially using a balance board, throwing, and catching (Reynolds, Nicolson \& Hambly, 2003). The foregoing movements were used to approximate behaviors as cues 
for learning needs of the participants in the present study. Another learning area, such as music, it was found out that when coached in brain gym, after one week, every participant rated brain gym as having a positive effect upon their playing. The same was found that every participant had a more positive opinion of brain gym than they had prior to the experiment (Moore \& Hibbert, 2005).

There were reports of negligible contribution of these perceptual motor programs in improving student performance. Albeit this, there has been little adjustment in notions about their effectiveness and they continue to be implemented in schools in the USA or United States of America (Kavale, 2007). Like in Australia, although Education Departments and others responsible for providing advice and professional development to teachers espouse research-based practice, they continue to endorse and support the use of brain gym (Stephenson, 2009).

In view of this, L. Spaulding, M. Mostert \& A.P. Beam (2010) examined some theoretical assumptions from which brain gym was developed, review the efficacy literature, and provide suggestions for making informed decisions about the judiciousness of investing time and resources in this program (Spaulding, Mostert \& Beam, 2010). It strengthens the need to align education from that of neuroscience research investments in order to judge their applicability to learning environments (Tokuhama-Espinosa, 2010).

Whatever issue or proposed solution is attached to behaviors of school learners, the ultimate objective for a research endeavor is to provide new insights of how to enhance learning and well-being in children (Uusiautti \& Maatta, 2016). The research attempted to approximate behaviors as cues for learning needs in reading among first grade learners.

\section{METHOD}

The class adviser assisted the researchers to identify the participants composed of 5 (five) first grade learners from a public school. The learners had academic marks lower than $80 \%$ after the first half of the school year. Accordingly, they had reading difficulties specifically on attention, expressive reading, focusing on test, reading comprehension, and spelling.

They were purposively selected on account of their extreme behaviors during reading sessions in class as observed by their current and former teachers (Miles \& Huberman, 1994; Shadish, Cook \& Campbell, 2002; Coburn, 2006; and Driscoll, 2011). Anchored on literature related to brain gym, the researchers developed a checklist on pupil's learning difficulties in reading and their bodily movements (Gibbs, 2007; FletcherCampbell, Soler \& Reid, 2009; and Fischer, 2010). Each behavior should manifest for a minimum of five seconds before it qualifies as cue for one count in frequency.

The researchers conducted several visits on site for initial class observation, acquaintance with the pupils, preparation of the instrument, and familiarity in the documentation of responses. The researchers came up with a standard procedure for utilizing the checklist to ensure proper documentation. Likewise, using the checklist, the researchers observed one participantlearner every scheduled reading class (Hughes et al., 2009; and Driscoll, 2011).

The researchers consulted experts who regularly use the Brain Gym Program for careful selection of exercises to approximate children's behaviors, while they encounter learning difficulty for reading (Koestner, 2000; Fergusson, Boden \& Horwood, 2010; and Ocampo, Jr., Varela \& Ocampo, 2017).

\section{RESULTS AND DISCUSSION}

See table 1. The same table depicts the pupil's behaviors when observed by the 
Table 1:

First Grade Learner's Attention and Their Behaviors

\begin{tabular}{lc}
\hline Attention & Frequency of Manifestation Per Pupil ( f ) \\
\hline Behavior Manifestation: & \\
Head: & $(2)$ \\
1. Bites bottle & $(1)$ \\
2. Bites lower lip while reading & $(1)$ \\
3. Looks around & $(1)$ \\
4. Moves the head & $(1)$ \\
5. Puts head on the table & $(1)$ \\
6. Yawns & \\
\hline Arm-Hand: & $(2)$ \\
1. Draws something & $(11)$ \\
2. Plays bottle & $(1)$ \\
3. Plays pencil & $(4)$ \\
4. Puts hand on the head & $(1)$ \\
5. Scratches head & $(1)$ \\
6. Stretches arms at the nape & $(1)(2)(3)$ \\
7. Touches the toes & $(1)$ \\
\hline Shoulder-Waist: & $(1)(2)$ \\
Moves the body forward and sideward while reading & $(5)(7)$ \\
\hline Waist-Feet: & $(1)(2)$ \\
1. Bounces and shakes the legs & \\
2. Places foot on chair & \\
3. Rocks the chair & Sits on the edge of an inclined chair \\
\hline
\end{tabular}

researchers during their reading activities, specifically on the aspect of Attention. They exhibited so many movements along the Waist-Feet region. While composing themselves for attention to activities, students enjoyed rocking their chair, seemingly searching for their balance beyond the normal limits. They seemed wanting to stimulate their consciousness to get ready for participation in class activities.

Many students were seen resting their feet on the chair. They probably wanted to feel the heat of their knees, while flexing their leg and thigh muscles. This behavior can increase their wakefulness well enough to respond to the proceedings of the lesson. Another sign of searching for their balance is the students' preference to incline the chair and sit on its edge. It is as risky as when they rock the chair, because they may fall on the floor with their butt first, or their head or the back portion of their body first.
With reference to the Shoulder-Waist region, the children would move their body forward and sideward while reading. This may be an instance indicating their search for balance. Occasions were also recorded when pupils would play with any object that they can hold like hanky, bottle, or jacket. Relative to the Head region, there were observations that pupils would bite the hanky or zipper of the jacket. It could be another case which may suggest that the pupil felt some tension while adjusting with the lesson.

The pupils exhibited only few behaviors relative to Focusing on Test. As may be seen in table 2 and with reference to the Waist-Feet region, the children seemed to enjoy inclining their chairs as they sit on the edge, while focusing on the test. Similar to previous observations, they felt comfortable establishing their focus in a risky manner. This awkward behavior probably provided 
Table 2:

First Grade Learner's Focusing on Test and their Behaviors

\begin{tabular}{lc}
\hline Focusing on Test & Frequency of Manifestation Per Pupil (f) \\
\hline Behavior Manifestation: & \\
Arm-Hand: & $(2)(3)$ \\
Plays with pencil & \\
\hline Shoulder-Waist: & $(1)$ \\
Slouches on the chair & \\
\hline Waist-Feet: & $(1)$ \\
1. Rocks the chair & $(1)(3)$ \\
2. Sits on the edge of an inclined chair & \\
\hline
\end{tabular}

Table 3:

First Grade Learner's Reading Comprehension and Their Behaviors

\begin{tabular}{lc}
\hline Reading Comprehension & Frequency of Manifestation Per Pupil ( f ) \\
\hline Behavior Manifestation: & \\
Arm-Hand: & $(5)$ \\
1. Draws something on a paper & $(1)$ \\
2. Plays with bottle & $(2)(2)$ \\
3. Plays with pencil & $(1)$ \\
4. Plays with rubber & \\
\hline Shoulder-Waist: & $(2)$ \\
Moves body forward & \\
\hline Waist-feet: & $(1)$ \\
1. Crosses legs & $(1)$ \\
2. Places foot on the chair & $(4)$ \\
3. Rocks the chair & $(2)$ \\
4. Sits at the arm rest & $(2)$ \\
5. Sits on the edge of an inclined chair & $(1)$ \\
6. Sits on the edge of chair & $(1)$ \\
7. Sways legs & \\
\hline
\end{tabular}

them with a more stimulating feeling, so they could respond to the test. It may create a more challenging activity for the brain, while their bodies had to move in a clumsy position, thus exposing them to the tendency of suffering from accidents which involve their bones and muscles.

The researchers were always on the verge of calling the pupils' attention, so they would refrain from sitting on the inclined chair. Along the same area, one pupil was seen rocking the chair, another behavior which required the learner to use his sense of balance.

With reference to the area on Arm and Hand, the pupils were caught playing with their pencils. They were manifesting extra movements from the said region, especially the hand, so they could maintain their wakefulness and stay directly focused on the activity. It may be hard to fathom, but seemingly for these children, focusing on the test was just like another paper and pencil test, and was not limited to using one's sense of sight. Of course they can respond to tests by reading the text of the exercise using their eyes, but with their hands also holding something and moving, or, playing with the said object.

Going to the Shoulder-Waist region, one pupil was seen slouching on the chair. His body was in a slanting position very close to a normal sleeping position. This gives sensation with partiality to the spine and 
Table 4:

First Grade Learner's Spelling and Their Behaviors

\begin{tabular}{lc}
\hline Spelling (Oral) & Frequency of Manifestation Per Pupil ( f) \\
\hline Behavior Manifestation: & \\
Head: & \\
(writing-sitting) & $(1)$ \\
1. Bites fingers & $(1)$ \\
2. Bites hand & $(1)(2)$ \\
3. Puts chin on the table & $(1)$ \\
4. Moves eyes side to side & $(1)(3)$ \\
\hline Arm-Hand: & \\
Plays with pencil & $(1)(2)$ \\
\hline Waist-Feet: & $(1)$ \\
1. Bounces/Shakes the legs & $(1)(1)(5)(5)$ \\
2. Raises foot & $(2)$ \\
3. Rocks the chair & $(2)(8)$ \\
4. Sits at inclined chair & $(2)$ \\
5. Sits on the edge of an inclined chair & \\
6. Stomps feet &
\end{tabular}

could facilitate the learner's concentration on answering the test.

As observed by the researchers, table 3 suggests that the pupils exhibited plenty of behaviors involving the Arm-Hand region. While performing the reading comprehension activity, top on the list of behaviors was of students drawing something on any paper. Were the students' sketches a representation of what they were reading? Did they create these images to relate with the story that they were trying to grasp?

The answers to these questions may lead one to think that this is how pupils attempt to stimulate their sense of imagination. They want to draw pictures. They want to portray actions, which could serve as a synthesis of the story (Dexter, 1999; Klein, 1999; and McCall, 2012). However, while doing these, some pupils were observed playing with a bottle or with rubber bond. This behavior can be considered as a sign of boredom or, probably, a signal of children's anxiety.

On the Waist-Feet area, many students were seen rocking their chairs. Some were observed sitting on the edge of an inclined chair or sitting on the arm rest. These three behaviors could represent the children's mechanisms to understand what they were reading. When they unconsciously lost their balance, this increased or triggered their ability to comprehend. This is a phenomenon which requires further observation and deeper explanation.

Along the same region, there were children who were seen putting their feet on the chair or crossing their legs. These could be behaviors which drove them to stretch their muscles in the lower part of their body, thus, enabling them to stimulate their focus on reading comprehension.

See table 4 . The second activity on reading where pupils exhibited a lot of behaviors was in spelling. Observing the pupils' Waist-Feet region, they were frequently seen rocking the chair or sitting on the edge of the chair. To ordinary observers, it may suggest that the pupils were experiencing restlessness. Some children would opt to bounce, or shake their legs or, sit on the edge of a chair while it was inclined. These behaviors apparently stress the idea that the children were creating these movements to facilitate the integration of their senses. 
Table 5:

First Grade Learner's Expressive Reading and Their Behaviors

\begin{tabular}{lc}
\hline Expressive Reading (Standing) & Frequency of Manifestation Per Pupil (f) \\
\hline Behavior Manifestation: & \\
Head: & $(1)$ \\
Yawns & $(1)$ \\
\hline Arm-Hand: & $(1)$ \\
1. Points pencil to the word & $(1)$ \\
2. Scratches the nape & $(1)$ \\
3. Stretches arms upward & \\
\hline Shoulder-Waist: & $(3)$ \\
Slouches on the chair & $(2)(2)$ \\
\hline (Sitting): & $(1)$ \\
1. Arm-Hand & $(1)$ \\
2. Bites fingers & $(2)$ \\
3. Bites pencil & \\
4. Plays pencil & $(1)$ \\
5. Scratches the feet & $(1)$ \\
\hline Waist-Feet: & $(1)$ \\
1. Places foot on the chair & $(3)$ \\
2. Rocks the chair & $(1)(3)$ \\
3. Sits on the edge of an inclined chair & \\
4. Sways the legs & \\
5. Stomps feet &
\end{tabular}

Table 6:

First Grade Learner's Specific Learning Difficulties with Corresponding Brain Gym Activities

\begin{tabular}{lllll}
\hline Attention & Expressive Reading & Focusing on Test & Reading Comprehension & Spelling \\
\hline The Elephant & Arm Activation & Space Buttons & Brain Buttons & Balance Buttons \\
The Owl & Belly Breathing & Alphabet 8s & Earth Buttons & Double Doodle \\
The Rocker & The Energy Yawn & Arm Activation & Space Buttons & The Cross Crawl \\
The Energizer & The Rocker & Double Doodle & The Gravitational Glider & Lazy 8s \\
Brain Buttons & Cross Crawl Sit-Ups & Neck Rolls & The Rocker & The Thinking Cap \\
\hline
\end{tabular}

The researchers observed that, relative to the Head region, there were children who tended to bend and drop their body to rest their chin on the table. This gives the opposite idea that, as children show clumsy and aggressive behaviors, their body would tend to work in an ascending manner where they would appear relaxed or look uninterested.

There were observations that individually, pupils resorted to biting their fingers or their hands, or to moving their eyes side to side. This may be an attempt for them to control some complexities on the body so as to trigger some sort of sensation. On observing the Arm-Hand region, children were caught playing with their pencils. This further indicates how active their body systems are and probably shows of inducing their spelling skills.

It can be gleaned from table 5 that the pupils exhibited a lot of behaviors on the area of Arm-Hand (while sitting). Many of them were observed biting pencils as well as biting their fingers. It is so unthinkable that, while doing expressive reading, they would do other things which involve their mouth area. It may mean they were trying to cope with the stressful situation which required efforts to concentrate and be expressive at the same time.

Observed on their Waist-Feet region, 
respondents were caught stomping their feet while standing to do expressive reading. It is more likely that pupils were drawing strength by engaging in some activity of their feet to reduce their jitters. It is worth emphasizing that among the reading activities, it was exclusively along this area that children demonstrated their performance while standing. Normally, learners find it difficult to stand before the class, because they become very conscious and worried about how their classmateobservers would evaluate their performance.

Concerning the Shoulder-Waist area, there were observations that the respondents would touch or scratch their nape. This could be an indication that the respondents were becoming unwilling to participate in expressive reading. While standing, and relative to the area of Arm-Hand region, there was one child who was caught with his mouth widely opened as if yawning. This may suggest that he was not ready for the said activity.

See table 6. By approximating the unusual bodily movements of first grade learners as cues for addressing their leaning needs, the researchers propose some physical exercises related to brain gym activities. It can be used for learners who have reading difficulty.

Developed by P.E. Dennison \& G.E. Dennison (1994 and 2010), the program promotes the idea that learning humps can be addressed by carrying out specific movements which stimulate pathways in the brain (Dennison \& Dennison, 1994 and 2010). Listed above are the specific reading difficulties and the corresponding brain gym activities.

\section{CONCLUSION}

The first grade learners' reading difficulties can be manifested through various behaviors. These behaviors are grouped and can be observed on four areas, such as head, arm-hand, shoulder-waist, and waist-foot. The approximate behaviors as cues for addressing learning needs have similar postures found in brain gym movements.

The recommendations are as following here: (1) Explore other areas of learning difficulty among school learners; and (2) Identify the learning difficulties in reading and the behaviors of school learners using the checklist constructed by the researchers. ${ }^{1}$

\section{References}

ADB [Asian Development Bank]. (2015). "Brain Drain versus Brain Gain: The Study of Remittances in Southeast Asia and Promoting Knowledge Exchange through Diasporas". Available online at: http://www.un.org/esa/ population/meetings/fourthcoord2005/P13 ADB.pdf [accessed in Manila, Philippines: January 7, 2017].

Coburn, C.E. (2006). "Framing the Problem of Reading Instruction: Using Frame Analysis to Uncover the Microprocesses of Policy Implementation" in American Educational Research Journal, 43(3), pp.343-379.

Dennison, P.E. \& G.E. Dennison. (1994). Brain Gym: Teacher's Edition. Ventura, CA: EduKinesthetics, Inc., revised edition.

Dennison, P.E. \& G.E. Dennison. (2010). Brain Gym. Ventura, CA: Edu-Kinesthetics, Inc.

Dexter, T. (1999). "Relationships between Sport Knowledge, Sport Performance, and Academic Ability: Empirical Evidence from GCSE Physical Education" in Jounal of Sports Sciences, Volume 17(4), pp.283-295.

Driscoll, Dana Lynn. (2011). "Introduction to Primary Research: Observations, Surveys, and Interviews" in Charles Lowe \& Pavel Zemliansky [eds]. Writing Spaces: Readings on Writing, Volume 2. USA [United States of America]: Parlor Press.

Dunlosky, John et al. (2013). "Improving Students' Learning with Effective Learning Techniques: Promising Directions from Cognitive and Educational Psychology" in Psychological Science in the Public Interest, 14(1). Available

\footnotetext{
${ }^{1}$ Statement: Herewith, we declare that this paper is our original work; it is not product of plagiarism and not yet be reviewed or published by other scholarly journals elsewhere.
} 
online also at: http://webcache.googleusercontent. com/search?q=cache:http://www.indiana. edu/ pcl/rgoldsto/courses [accessed in Manila, Philippines: August 5, 2017].

Feldman, D. et al. (2003). "Is physical Activity Differentially Associated with Different Types of Sedentary Pursuits?" in Arch. Pediatr. Adoles. Med., Vol.157, pp.797-802.

Fergusson, D.M., J.M. Boden \& L.J. Horwood. (2010). "Classification of Behavior Disorders in Adolescence: Scaling Methods, Predictive Validity, and Gender Differences" in Journal of Abnormal Psychology, 119, pp.699-712.

Fischer, K. (2010). "The Future of Neuroscience" in Mind, Brain, and Education, Vol.4, No.2, pp.68-80.

Fletcher-Campbell, F., J. Soler \& G. Reid. (2009). Approaching Difficulties in Literacy Development: Assessment, Pedagogy, and Programmes. Los Angeles, CA: SAGE Publications.

Formosa, P. (2009). Fraid Not! Empowering Kids with Learning Differences. New York and Bloomington: i-Universe, Inc.

Gibbs, Karen L. (2007). "Study Regarding the Effects of Brain Gym on Student Learning” in Education and Human Development Master's Theses, 413. Available online also at: http://digitalcommons. brockport.edu/ehd theses/413 [accessed in Manila, Philippines: January 7, 2017].

Hannaford, C. (1997). The Dominance Factor. Utah: Great River Books.

Hughes, Denise et al. (2009). Best Practices for Physical Activity: A Guide to Help Children Grow Up Healthy for Organizations Serving Children and Youth. Florida: The Nemours Foundation. Available online also at: https://www.nemours. org/content/dam/nemours/www/filebox/service/ preventive/nhps/paguidelines.pdf [accessed in Manila, Philippines: January 7, 2017].

Kavale, K.A. (2007). "Quantitative Research Synthesis: Meta-Analysis of Research on Meeting Special Education Needs" in L. Florian [ed]. The SAGE Handbook of Special Education. London: Sage Publications, pp.207-221.

Klein, P. (1999). "Reopening Inquiry into Cognitive Processes in Writing-to-Learn" in Educational Psychology Review, Vol.11, pp.203-270.

Koestner, C. (2000). “A Summary of a Brain Gym Research Project on Reading" in Brain Gym Journal, Issue of December. Available online also at: http://www.iamthechild.com/articleresearch/ articlereading.html [accessed in Manila, Philippines: August 5, 2017].

Koester, C. \& G. Dennison. (2010). I am the Child: Using Brain Gym with Children Who Have Special Needs. Ventura, California: Edu-Kinetics, Inc.
Mahar, M. et al. (2006). "Effects of a ClassroomBased Program on Physical Activity and On-Task Beahavior" in Medicine \& Science in Sports \& Exercise, pp.2086-2094.

Maskell, B., D.R. Shapiro \& C. Ridley. (2004). "Effects of Brain Gym on Overhand Throwing in First Grade Students: A Preliminary Investigation" in Physical Educator. Late Winter. Available online also at: http://web.b.ebscohost. com.ezpustaka.upsi.edu.my/ehost/delivery?sid [accessed in Manila, Philippines: August 1, 2017].

McCall, L. (2012). "Brain-Based Pedagogy in Today's Diverse Classrooms: A Perfect Fit But Be Careful!" in The Delta Kappa Gamma Bulletin, on Professional Development.

Miles, M. \& M. Huberman. (1994). Qualitative Data Analysis: An Expanded Sourcebook. Thousand Oaks: Sage Publications, 2nd edition.

Moore, H. \& F. Hibbert. (2005). "Mind Boggling! Considering the Possibilities of Brain Gym in Learning to Play an Instrument" in British Journal of Music Education. Available online also at: http://dx.doi.org/10.1017/S0265051705006479 [accessed in Manila, Philippines: August 1, 2017].

Ocampo, Jr., Jose M. (2015a). “Children's Reading Difficulty and Their Perceived Misbehavior" in SIPATAHOENAN: South-East Asian Journal for Youth, Sports \& Health Education, Volume 1(2), October, pp.199-208. Bandung, Indonesia: Minda Masagi Press, APAKSI Bandung, and KEMENPORA RI Jakarta, ISSN 2407-7348.

Ocampo, Jr., Jose M. (2015b). “Identification and Reduction of Children's Learning Difficulty and Their Misconstrued Misbehavior". Paper presented in the Hawaii University International Conferences, S.T.E.A.M. \& education, on June 13-15, at Ala Moana Hotel, Honolulu, Hawaii, USA [United States of America]. Available online also at: https://www.huichawaii.org/ assets/ocampo\%2C-jose- -2015-stem-huic.pdf [accessed in Manila, Philippines: August 1, 2017].

Ocampo, Jr., Jose M., Leonora P. Varela \& Laura V. Ocampo. (2017). "Effectiveness of Brain Gym Activities in Enhancing Writing Performance of Grade I Pupils" in SOSIOHUMANIKA: Jurnal Pendidikan Sains Sosial dan Kemanusiaan, Volume 10(2), November, pp.179-190. Bandung, Indonesia: Minda Masagi Press and UNIPA Surabaya, ISSN 1979-0112.

Otto, Michael W. \& Stefan G. Hofmann [eds]. (2010). Avoiding Treatment Failures in the Anxiety Disorders. New York: Spinger. Available online also at: https://www.researchgate.net/ profile/Matthew Nock/publication [accessed in Manila, Philippines: August 1, 2017].

Reynolds, D., R. Nicolson \& H. Hambly. (2003). 
"Evaluation of an Exercise-Based Treatment for Children with Reading Difficulties" in Dyslexia, 9, pp.48-71.

Sarivaara, E. (2018). "Transformational Elements for Learning Outdoors in Finland: A Review of Research Literature" in International Journal of Research Studies in Education, Volume 7, Number 3, pp.73-84.

Shadish, W.R., T.D. Cook \& D.T. Campbell. (2002). Experimental and Quasi-Experimental Designs for Generalized Causal Inference. Boston: Houghton Mifflin Company.

Sibley, B. \& J. Etnier. (2003). "The Relationship between Physical Activity and Cognition in Children: A Meta-Analysis" in Pediat. Exercise Sci., Vol.15, pp.243-256.

Spaulding, L., M. Mostert \& A.P. Beam. (2010). "Is Brain Gym ${ }^{\circledR}$ an Effective Educational Intervention?" in Exceptionality, Volume 18(1). Available online also at: http://search.proquest. com/docview/208970758? accountid=13155 BrainGym [accessed in Manila, Philippines: December 3, 2017].

Stephenson, J. (2009). "Best Practice? Advice Provided to Teachers about the Use of Brain
Gym ${ }^{\circledR}$ in Australian Schools" in Australian Journal of Education, Vol.53, No.2, pp.109-124.

Tambychick, T. (2010). 'Students' Difficulties in Mathematics Problem-Solving: What Do They Say?" in PROCEDIA: Social and Behavioral Sciences, Volume 8, pp.142-151. Available online also at: http://www.ac.els.com/ [accessed in Manila, Philippines: 26 ${ }^{\text {th }}$ August 2017].

Tokuhama-Espinosa, T. (2010). Mind, Brain, and Education Science: The New Brain-Based Learning. New York: W.W. Norton.

Ulrich, D.A. \& C.B. Sanford. (2000). Test of Gross Motor Development Examiner's Manual. Austin, TX: Pro-ed, $2^{\text {nd }}$ edition.

Uusiautti, S. \& K. Maatta. (2016). The Basics of Caring Research. Rotterdam: Sense Publishers. Available online also at: https://doi. org/10.1007/978-94-6300-597-5 [accessed in Manila, Philippines: December 12, 2017].

Watson, A. \& G. Kelso. (2014). "The Effect of Brain Gym on Academic Engagement for Children with Developmental Disabilities" in Internaional Journal of Special Education, pp.1-9. Available online also at: www.files.eric.edu [accessed in Manila, Philippines: $17^{\text {th }}$ March 2017]. 